\title{
Feeding and growth coupling during different development larvae phases of the Mediterranean mussel Mytilus galloprovincialis L. from Amsa Bay
}

\author{
Mohamed Ali El Moussaoui ${ }^{1}$, Yassine Ouagajjou ${ }^{2, *}$, Adil Aghzar $^{3}$, El Mustafa Ait Chattou ${ }^{2}$, Younes Saoud ${ }^{1}$, and Hassan \\ Nhhala ${ }^{4}$ \\ ${ }^{1}$ Faculty of Science, Abdelmalek Essaadi University, Tétouan 93002, Morocco \\ ${ }^{2}$ National Institute of Fisheries Research (INRH), Amsa 93022, Morocco \\ ${ }^{3}$ Higher School of Technology, Sultan Moulay Slimane University, Khénifra 54000, Morocco \\ ${ }^{4}$ Faculty of science and techniques, University of Abdelmalek Essaadi, Tanger 90060, Morocco
}

\begin{abstract}
Spat supply for mussel farming in Morocco is essentially based on seed capture and collection from natural beds. However, natural irregularity recruitment in exploited areas and encountered difficulties during spat collection operations have led to develop and improve reproduction techniques under controlled conditions in hatcheries. The present study focused on the larvae phase aiming at assessing growth rate varies between different development stages. Trocophore larva stage had a size of $63.25 \mu \mathrm{m}$ and reached the pedivilegere stage with a size of $272.56 \mu \mathrm{m}$ in 18 culture days. Length growth was more significant than width growth for both H-batch and T-batch. For instance, larvae grew in terms of length quickly in H-batch than T-batch $\left(11.10 \pm 1.30\right.$ and $\left.9.67 \pm 1.17 \mu \mathrm{m} \mathrm{day}^{-1}\right)$, and the same pattern was observed for T-batch larvae. Inversely, the total biomass consumed was higher during T-batch larvae rearing than H-batch ones. In contrast, the effect of feeding on growth was observed more significantly for $\mathrm{H}$-batch larvae $(\mathrm{t}=7.55, \mathrm{df}=23$, $\mathrm{p}<0.001)$ than $\mathrm{T}$-batch ones $(\mathrm{t}=4.13, \mathrm{df}=23, \mathrm{p}<0.001)$. However, the specific feeding effect was revealed higher for I. galbana for both batches rather than C. calcitrans and T. suecica. However, the larvae growth reduction is linked to the beginning of tissue synthesis.
\end{abstract}

\section{Introduction}

For decades, shellfish farming is mainly based on the availability of wild spat $[1,2]$. The question of sufficiency in terms of spat supply for shellfish industry [3] linked to ecological problems [4] has emphasized studies related to hatchery spat production [5]. Optimization in bivalve hatchery productivity requires, among others, assessment of multi-species algae as feeding diets to enhance growth and survival during the larval phase.

Many studies have been carried out on bivalves to understand and improve the spat production process in this context. Such studies have successfully optimized conditions for the growth and survival of bivalve larvae in hatcheries $[6,7]$, while other studies have been based on physiological parameters [8]. Microalgae are the main source of nutrition in bivalves [9]. However, information on algae composition and larval food requirements for a high growth rate are limited [10]. Microalgae culture is so influential because it is the only feed source for bivalve larvae [11]. A large percentage of shellfish production cost is expended on feed [12, 13]; it represented almost $30 \%$ of the production cost [14]. Some commonly used micro-algae species as mussel larvae feed include Isochrysis galbana, Isochrysis galbana Tahiti strain, Chaetoceros calcitrans, C. muelleri, C. gracilis, Tetraselmis suecica, Skeletonemacostatum, Rhodomonas lentil, Pavlova lutheri, and P salina $[15,16]$.

Pelagic larvae require particular conditions for their development and metamorphosis to post-larvae (benthic larvae); this process requires an adequate food supply (type and concentration of phytoplankton), suitable environmental conditions, notably temperature [17] and physiological factors [18]. This research aims to summarize and review the latest literature on the development, feeding, metabolism, and growth of mussel larvae, emphasizing their physiological responses in their different stages until the settlement phase. Moreover, it highlights knowledge on the nutritional needs of mussels' larvae and improves their survival.

\section{Materials and Methods}

\subsection{Spawning and fertilization}

Spawning was induced triggered by a thermal technique where mussels broodstock were submitted alternatively to two different temperature seawater conditions, first cold $\left(14 \pm 1.5^{\circ} \mathrm{C}\right)$ then hot $\left(26 \pm 1.0^{\circ} \mathrm{C}\right)$. After repeating

\footnotetext{
*Corresponding author: ouagajjou@inrh.ma
} 
this treatment twice, males and females of mussel broods started laying their gametes; then, each spawned individual was placed separately in a single small container leaving them to continue releasing their gametes. Fertilization was performed based on a ratio of about 50 to 100 sperm per oocyte.

\subsection{Larvae rearing}

Freshly hatched larvae were reared in $0.2 \mu \mathrm{m}$ filtered seawater under controlled conditions of temperature (22 $\left.\pm 0.8{ }^{\circ} \mathrm{C}\right), \mathrm{pH}(7.8 \pm 0.15)$, and salinity (36.6 PSU). Larval rearing seawater was changed each day (48h), and larvae were sieved for sizes screening and daily growth rate estimates. Fifteen larvae were randomly sampled in each $48 \mathrm{~h}$ renewal rearing seawater culture for biometry measurement (length and width).

\subsection{Larvae feeding}

Isochrysis galbana, Tetraselmis suecica. And Chaetoceros calcitrans) They were used as the three microalgae strains to feed reared larvae in this study. First, during the early larvae stages, only I. galbana and C. calcitrans were supplied as food based on 1,300 cells/larvae and 700 cells/larvae) respectively. Later, since culture day 8, T. Suecica was introduced in the feeding regime with 750 Cells/larvae.

\subsection{Statistical analysis}

Statistical analysis was performed using the Rcmdr interface [19] implemented in $\mathrm{R}$ package version 3.0.4 [20]. The test student was handled to reveal the effect of microalgae consumed biomass on larvae growth rate.

\section{Results}

Table 1 shows the length and width gain of larvae and their consumption variation in terms of micro-algae according to two slices head batch (H-batch) and Tail batch (T-batch). Generally, the H-batch larvae grow quickly $\left(11.10 \pm 1.30 \mu \mathrm{m}\right.$ day $\left.^{-1}\right)$ compared to the T-batch $\left(9.67 \pm 1.17 \mu \mathrm{m} \mathrm{day}^{-1}\right)$. Inversely, in terms of consumed biomass of microalgae, the latter showed a high consumption (4708.21 ng. Larvae ${ }^{-1}$ ) compared to the $\mathrm{H}$ batch slice (4053.81 ng. Larvae ${ }^{-1}$ ) (Table 1). This can be explained by the fact that larvae use their consumed nutrients more in their tissues synthesis than in their growth. In terms of specific consumption, $T$. suecica is more consumed in biomass in both H-batch and T-batch with values of $2431.85 \mathrm{ng}$ Larvae $^{-1}$ and $2970.43 \mathrm{ng}$ Larvae $^{-1}$ followed by I. galbana with $1226.47 \mathrm{ng}^{2}$ Larvae$^{-}$ 1 and $1290.75 \mathrm{ng}$ Larvae $^{-1}$, respectively. On the other hand, I. galbana showed a significant effect of microalgae consumption on the growth rate of mussel larvae during different development phases and both slices $\mathrm{H}$ batch $\left(\mathrm{T}=9.21 ; \mathrm{df}=23 ; \mathrm{p}\right.$-value $\left.=3.55 \times 10^{-9}\right)$ and $\mathrm{T}$-batch $\left(\mathrm{T}=6.24 ; \mathrm{df}=23 ; \mathrm{p}\right.$-value $\left.=2.32 \times 10^{-6}\right)($ Table 2$)$.
Table 1. Length and width variation for head batch (H-batch) and Tail batch (T-batch) regard consumed biomass of microalgae. LG (length gain), GR (growth rate).

\begin{tabular}{|c|c|c|c|c|c|}
\hline & & \multicolumn{2}{|c|}{ H-batch } & \multicolumn{2}{|c|}{ T-batch } \\
\hline & & Length & Width & Length & Width \\
\hline \multirow{2}{*}{ 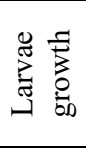 } & $\mathrm{LG}(\mu \mathrm{m})$ & $\begin{array}{c}210.45 \pm \\
3.29\end{array}$ & $\begin{array}{c}180.45 \pm \\
2.52\end{array}$ & $\begin{array}{c}195.25 \pm \\
15.05\end{array}$ & $\begin{array}{c}162.5 \pm \\
10.38\end{array}$ \\
\hline & \begin{tabular}{|c|} 
GR \\
$(\mu \mathrm{m} /$ day $)$
\end{tabular} & $\begin{array}{c}11.10 \pm \\
1.30 \\
\end{array}$ & $\begin{array}{c}9.95 \pm \\
2.31 \\
\end{array}$ & $\begin{array}{c}9.67 \pm \\
1.17 \\
\end{array}$ & $\begin{array}{c}6.67 \pm \\
2.14 \\
\end{array}$ \\
\hline \multirow{4}{*}{ 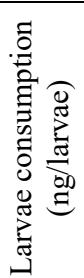 } & $\begin{array}{c}\text { I. } \\
\text { galbana }\end{array}$ & \multicolumn{2}{|c|}{1226.47} & \multicolumn{2}{|c|}{1290.75} \\
\hline & \begin{tabular}{|c|}
$\mathrm{C}$. \\
calcitrans
\end{tabular} & \multicolumn{2}{|c|}{395.49} & \multicolumn{2}{|c|}{447.03} \\
\hline & $\begin{array}{c}\mathrm{T} . \\
\text { suecica } \\
\end{array}$ & \multicolumn{2}{|c|}{2431.85} & \multicolumn{2}{|c|}{2970.43} \\
\hline & Total & \multicolumn{2}{|c|}{4053.81} & \multicolumn{2}{|c|}{4708.21} \\
\hline
\end{tabular}

Table 2. Statistical analysis (test $t$ ) of the effect of microalgae consumption on the growth rate of mussel larvae during different development phases. $\mathrm{T}$ (test student), df (degree of freedom), ${ }^{* * *}$ significant at $\mathrm{p}<0.001$

\begin{tabular}{|c|c|c|c|}
\hline t-test (student) & $\mathbf{t}$ & df & p-value \\
\hline \multicolumn{4}{|c|}{ Head batch larvae } \\
\hline I.galbana/growth rate & 9.21 & 23 & $3.55 \times 10^{-9}$ \\
\hline C.calcitrans/growth rate & 7.00 & 23 & $3.90 \times 10^{-7}$ \\
\hline T.suecica/growth rate & 7.80 & 14 & $1.84 \times 10^{-6}$ \\
\hline Total consumption/growth rate & 7.55 & 23 & $1.14 \times 10^{-7}$ \\
\hline \multicolumn{4}{|c|}{ Tail batch larvae } \\
\hline I.galbana/ growth rate & 6.24 & 23 & $2.32 \times 10^{-6}$ \\
\hline C.calcitrans/growth rate & 3.82 & 23 & $8.80 \times 10^{-4}$ \\
\hline T.suecica /growth rate & 3.69 & 14 & $2.44 \times 10^{-3}$ \\
\hline Total consumption/growth rate & 4.13 & 23 & $4.06 \times 10^{-4}$ \\
\hline
\end{tabular}

\section{Discussion}

In this study, it has been noted that the consumption rate varied between the different larval development stages of larval development. It was equal to $84 \%$ in the D larval stage; then, it decreased to $68 \%$ in the viligere stage before increasing to 84 in the pediveligere stage. It has also been noted that consumption in the first stages depends on two species I. galbana and C. calcitrans. The consumption of $T$. suecica was small due to the contribution of the other two species. However, when larvae increase in size, particularly since the veliger stage, they begin to consume more $T$. suecica than $I$. galbana while their $C$. Calcitrans remains almost the same. These results indicated that the consumption rate is related to the morphological character of the alga itself, such as size and shape, which could make it challenging to be ingested by small size larvae spatially during early larvae development [18].

During the veliger phase, the growth has been increased from 10 to $20 \mu \mathrm{m} /$ day after the introduction of $T$. suecica. However, the growth decreased during the late larvae development phase, although the consumption rate continued to increase, specifically for $C$. calcitrans and $T$. 
suiseca (97 and 80\%, respectively). Moreover, the last days of larvae development, particularly in the pedivileger stage, are characterized by larval rapid morphological and physiological changes likely influenced by their growth [21]. Cells' size and morphology of used microalgae can determine feeding factors that influence pediveliger larvae. I. galbana and C. calcitrans are smaller in size than $T$. suecica. However, the sizes of these three algae are within the acceptable range of feeding for bivalve larvae, with an anteroposterior size higher than $210 \mu \mathrm{m}$ [22, 13]. The higher biomass consumption observed for T-batch larvae could be clearly explained by the high heterogeneity of larvae batch (eyespot and pediveliger). During this late phase, the mainstream larvae were using nutrients for tissue and organ synthesis rather than growth.

Many authors reported that combining different microalgae species as a food promotes better larval growth and survival than a mono-species diet in some bivalve species [11, 15, 23]. Moreover, [14] have reported that $T$. Tetrahele as mono-regime for $P$. viridis larvae nutrition cannot meet their needs [13]. [24] have found that the use of $T$. Suecica gave a low growth rate in $P$. generosa. According to [25], feeding based on only one type of microalgae can affect the growth rate of larvae, while mixed diets feeding, composed at least by one type of flagellate and one type of diatoms, has been shown to produce optimal growth and development of bivalve larvae [25, 26, 27].

\section{Conclusion}

In conclusion, microalgae feeding plays a crucial role in mussels' production; it is considered the only nutrient source in the larvae culture of bivalves. As showed in this study, and according to scientific literature, growth performance is high when a mixed diet is given instead of a single source of feed. The increase in consumption rate reflected physiological need increases; however, when their size exceeds $150 \mu \mathrm{m}$, larvae begin to prefer larger-sized microalgae with more nutritional components such as T. suecica and C. calcitrans. The growth rate remains constant in the pedivelligere stage characterized by morphological change, mainly foot appearance and shifting habits from pelagic to benthic life. In this phase, mussels' larvae prepare their fixation phase required for their metamorphosis process.

\section{References}

1. L.S Incze, R.A Lutz. Mussel culture: an east coast perspective. Pp. 99-140. In: R.A Lutz (ed.). Mussel Culture and Harvest: A North American Perspective. Elsevier Sci. Publ. Co., Amesterdam (1980)

2. R.W. Hickman, Mussel cultivation. In: The mussel Mytilus: ecology, physiology, geneticsand culture [ed. by Gosling, E]. Amsterdam, TheNetherlands: Elsevier Science PublishersBV.465-510 (1992)

3. J. Caceres-Martinez, A. Figueras, J Shellfish Res. 17:153-157 (1998)
4. M. Holmer, K. Black, C.M. Duarte, N. Marba, I.Karakassis, Aquaculture in theEcosystem.Netherlands: Springer (2008)

5. A. Aghzar, M. Miñambres, P. Alvarez, P. Presa, Thalassas 29: 9-16 (2013)

6. da Costa F., Cerviño-Otero A., Iglesias Ó., Cruz A., Guévélou E., Aquaculture International 28:1675-1708 (2020)

7. Y. Ouagajjou, T. El Aloua, M. El Moussaoui, El M. AitChattou, A. Aghzar, Y. Saoud, AACL Bioflux, 13: 3664-3673 (2020).

8. D. Matias, S. Joaquim, A.M. Matias, A. LeitãoInvertebrReprodDev, 60:49-58 (2016)

9. Knauer J, Southgate PC. Rev Fish Sci 7:241-280 (1999)

10. Rico-Villa B, Le Coz JR, Mingant C, Robert R. Aquaculture 256: 377-388 (2006)

11. I. Laing, Aquaculture 65,243-249 (1987)

12. P. Coutteau, FAO fish technical paper 361. FAO, Rome, pp 7-48 (1996)

13. M.M. Helm, N. Bourne, A practical manual. FAO fish technical paper 471. FAO, Rome, pp 59-83 (2004)

14. S. Rivero-Rodriguez, A.R. Beaumont, M.C. LoraVilchis, Aquaculture 263, 199-210 (2007)

15. P.C. Southgate, A.C. Beer, P.F. Duncan, R. Tamburri, Aquaculture 162: 247-257 (1998)

16. Ehteshami F, Romano N, RamezaniFard E, Hoseinzadeh SH (2016). AquacultNutr 23:671-680

17. Madrones-Ladja JA, dela Peña MR, Parami NP. Aquaculture 206:313-321 (2002)

18. Webb KL, Chu FLE-special publication no. 2, Louisiana State University Division of ContinuingEducation, Lewes/Rehoboth Beach, Delaware USA, pp 272-291(1982)

19. J. Fox, Bouchet-Valat, M. Rcmdr. R Commander. R package version 2.3-1 (2016)

20. R DevelopmentCore Team. R: RFoundation for Statistical Computing, Vienna, Austria (2008)

21. J.r H. Maquirang, F L. Pedroso, M J Apines-Amar, L.A G. Piñosa, D C. Rendaje, J F. Cadangin, Fedelia F C. Mero1 · Carlos C. Baylon. Aquaculture, (2019)

22. Utting SD, Spencer BE. Laboratory leaflet number 68, Ministry of Agriculture, Fisheries and Food, Directorate of Fisheries Research (1991)

23. Aarab L, Pérez-Camacho A, del Pino V-Toledo M, de ViçoseGC,Fernández-P H, Molina L. AquacultInt21:1065-1076 (2013)

24. Liu W, Pearce CM, McKinley RS, Forster IP. Aquaculture452:326-341 (2016)

25. Galley, T.H., Batista, F.M., Braithwaite, R., King, J., Beaumont, A.R.,. Aquaculture International 18, 315325 (2009)

26. Laing, I., Ministry of Agriculture, Fisheries and Food Directorate of Fisheries Research, Lowestoft. (1991)

27. Martinez-Fernandez, E., Southgate, P.C., Aquaculture 263, 220-226 (2007) 